\title{
The Effect of Fighting Spirit, Confidence and Motivation Towards Students Readiness for Work
}

\author{
Reni Susanti ${ }^{1}$, Agus Irianto ${ }^{2}$, Syamwil ${ }^{3}$ \\ 1Faculty of Economics, Universitas Negeri Padang, Padang, Indonesia \\ $\triangle$ (e-mail) resan_pgry@yahoo.co.id \\ ${ }^{2}$ Dept. of Economics Education, Faculty of Economics, Universitas Negeri Padang, Padang, Indonesia \\ ${ }^{3}$ Dept. of Economics Education, Faculty of Economics, Universitas Negeri Padang, Padang, Indonesia
}

\begin{abstract}
This study aims to reveal the influence of the fighting spirit, confidence and motivation on students' readiness for work. This study is descriptive and associative research. The population in this study was 389 students of class XII at vocational high school majoring business management in Tanah Datar and Padang Panjang. The sample was selected using proportional random sampling technique resulted with 198 students. The data collection technique was a survey questionnaire. The data analysis technique used is path analysis. The results of this study indicate that the power struggle a significant effect on motivation, confident attitude Significantly influence the motivation, willpower significant effect on the readiness to enter the workforce, confident attitude Significantly influence the readiness to enter the world of work, and motivation Significantly influence the readiness to enter the world of work,
\end{abstract}

Keywords: fighting spirit, attitude confidence, motivation, and students' readiness for work

\section{Introduction}

Education is a physical exercise, mental and moral for the individual to become a man of culture. Through education, individuals are expected to fulfill his duty as a human being created by God as a perfect being, and was elected leader of the earth and become citizens of a meaningful and useful for a country. Also no less important than that education is one elegant way to cut the chains of poverty.

The quality of human resources is seen as one of the key factors. The more openness the competition and the demands of the world of work also requires qualified human resources with all of their competence, able to develop themselves and jointly build nation. One of the businesses in improving the quality of human resources is through education.

Educational path divided into three, namely formal education, non-formal education and formal education informal. Educational obtained through other educational institutions are schools that are tiered education of poor education up to the highest level. Study on formal education consisted of basic education (elementary, middle), secondary education (high school, vocational) and higher education (Diploma, Bachelor).

One type of school or secondary educational institutions that can be expected to meet the needs of middle-level manpower is a vocational high school (SMK), where together we know that the motto is "SMK CAN". In education at vocational schools be improved adjustment of the contents of education (curriculum) systems, methods, learning tools teacher's professional ability and so on, so that the school is able to meet the needs of the business or industry.

Vocational School (SMK) is a formal education who have special training pattern for directing students to become graduates who are ready to plunge in a professional manner and also move in the world of business or company. According to the National Education System Law Article 15 Ministry of Education (2006: 8) states that vocational education is secondary education that prepares students to work in a particular field.

The main mission of vocational schooll is to prepare the students as prospective workers who have entered the world of readiness for working world. Presence of vocational school required to meet the needs of the community is that power of work. So, learners are required to have skills and a 
professional attitude in the field.

According to research Atlay in Caballero (2011) stated that job readiness is an important selection criterion in assessing potential graduates and career advancement in the performance of their future vocational. Existence SMK in preparing middle-level manpower skilled still needs to be improved. Because Not all vocational school graduates to meet the demands of jobs corresponding specialization.

Based on data from the Central Bureau of Statistics (BPS) of West Sumatra in February 2015, open unemployment in West Sumatra most also come from vocational school graduates, $11.75 \%$ and $11.40 \%$ of university graduates and graduates who completed primary school at the bottom of downward ie 2,44\%, and in February 2016 the unemployment rate rose again SMK by $0.79 \%$ compared to 2015 , which became $12.54 \%$. This illustrates the gap between the needs of the world of work with labor supply of institutions of vocational education, plus more of the results I have found during the initial observation, the data obtained from the search graduated from the three schools in vacational school Business Management in Tanah Datar and Padang Panjang city as follows:

Table 1 List of Business Management Graduates of Vocational High schools in Tanah Datar and Padang Panjang

\begin{tabular}{ccccccc}
\hline \multirow{2}{*}{$\begin{array}{c}\text { Graduation } \\
\text { year }\end{array}$} & $\begin{array}{c}\text { Number of } \\
\text { graduates }\end{array}$ & \multicolumn{3}{c}{ Activities after graduation } & No \\
\cline { 3 - 6 } activities & Working & College & $\begin{array}{c}\text { Entre- } \\
\text { preneurship }\end{array}$ & Total (\%) & \\
\hline 2014 & 416 & 83 & 48 & 14 & $145(34 \%)$ & 271 \\
\hline 2015 & 432 & 85 & 67 & 17 & $169(39 \%)$ & 263 \\
\hline 2016 & 438 & 71 & 31 & 20 & $122(27 \%)$ & 316 \\
\hline Total & 1286 & 239 & 146 & 51 & & 850 \\
\hline
\end{tabular}

Source: Data from Management Business vocationa schools in Tanah Datar and Padang Panjang.

Table 1 shows of 1286 students were only 239 students (only 18.58\%) who had to get a job, or if it represented overall no more than $40 \%$, which has working activity, lectures or self-employed each year, while another $60 \%$ had activity unclear. This illustrates not yet achieved the goal of creating a vocational school graduates are prepared for work.

Of the phenomenon described above, the author is interested in conducting research with the title: "Influence of Power struggle, Attitude Confidence and Motivation on Readiness Entering the World of Work in Business Management Students of SMK Tanah Datar and Padang Panjang".

According to Slameto $(2010,113)$ readiness is the overall condition of a person that makes it ready to give a response / answer in a particular way to a situation. Adjustment in condition will someday affect or inclination to respond. According to Dalyono $(2010,167)$ based on the principles of developmental readiness (readiness), it is clear that what has been achieved by a person in times past would have meaning for his activities now. What has happened in the present will contribute to the readiness (readiness) of individuals in the future.

A difficult situation can shape a person's ability to cope with a problem. In the face of a difficult situation, one can determine how her attitude. A person can choose to avoid and resolve or confront and overcome these obstacles. According Stlotz (2007), the power struggle is an individual's ability to face and overcome obstacles or difficulties of everyday tough and persevere regardless of the obstacles that exist around and focus on the goal. Phoolka and Kaur (2012) state that the power struggle is the ability to survive in a difficult situation and treat the condition.

According Nophrianti $(2015,21)$, the power struggle is a person's ability to use his intelligence to direct themselves and changing the perspective and behavior when faced with a situation that makes 
the powerless. Confident attitude is an attitude that can be grown from being able to stand on its own, able to master ourselves and free from the control of others and how we judge ourselves each others judge us, so that it can deal with any situation. Expressed in psychology dictionary that confidence is a belief in themselves sufficient ability and realize capabilities, and can use it properly. According Lauster $(2012,4)$ states that self-confidence is an attitude or feeling confident in the ability of self so that the persons concerned are not overly anxious in his actions, feel free to do things in their own right and responsible for his actions, warm and courteous in berintraksi with others,

Motivation is the drive in a person that influence his actions to achieve goals. Motivation is very important need for people who are looking for work, with the motivation that person will make every effort to get the job done. According to Uno $(2011,1)$, the motivation is the basic impulse that drives a person to behave". These impulses are in a person who moves to do something in accordance with the impulse itself, therefore one's actions based on the specific motivations contains a theme in accordance with the underlying motivation. According Sumadi Suryabrata as cited by Djaali (2012, 101), motivation is a state located in one who encouraged him to perform certain activities in order to achieve a goal.

\section{Research Methods}

This type of research is classified in descriptive and associative. According to Iskandar $(2009,61)$ descriptive study associative is research to provide a description of the phenomenon or social phenomena studied by describing about the value of independent variables, either one or more variables based on the indicators of studied in order to influence between two or more variables, or the influence of exogenous and endogenous variables. The population in this study were 389 Business Management students in class XII at vocational schools in Tanah Datar and Padang Panjang. The sample was selected using proportional random sampling technique. The data were collected using a survey questionnaire administered to 198 people.

The analysis used in this research was path analysis. Path analysis is an extension of the multiple linear regression analysis. Path analysis provides the amount of direct and indirect relationships between exogenous and endogenous variables (Irianto, 2014, 284). Exogenous variables are variables that no arrows toward him and endogenous variables are variables that are the cause of ekspilisitnya and there are arrows headed towards it. Figure 1 below shows the path analysis model used in this study.

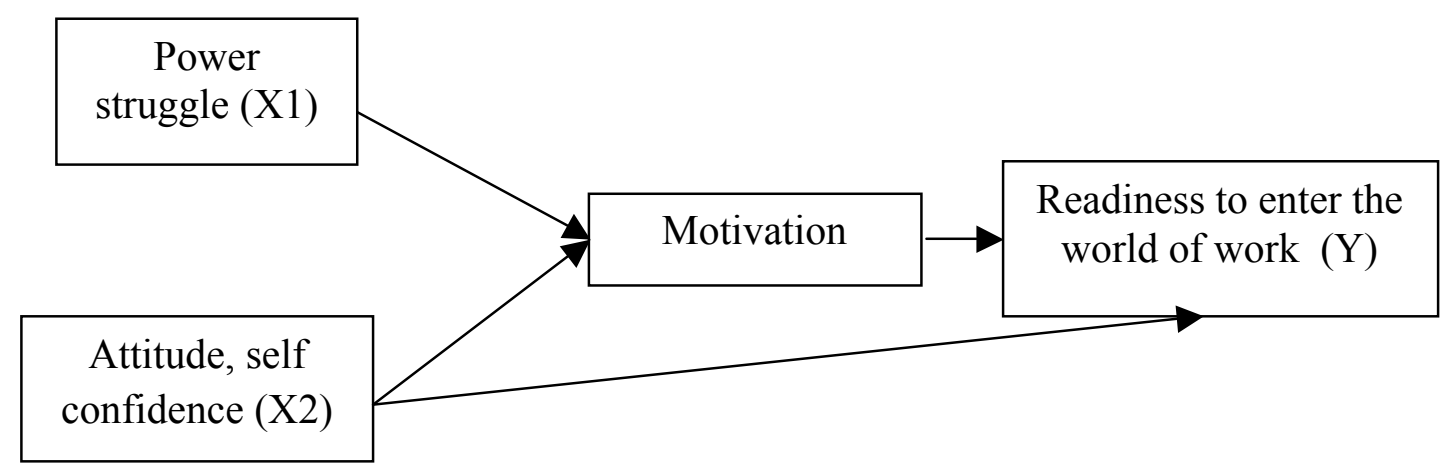

Figure 1 Structural Relationships $\mathrm{X}_{1}, \mathrm{X}_{2}$, and $\mathrm{X}_{3}$ on $\mathrm{Y}$

\section{Results and Discussion}

Based on the results of the study Effects of willpower $\left(X_{1}\right)$, a confidence $\left(X_{1}\right)$ and motivation $\left(\mathrm{X}_{1}\right)$ on readiness to enter the workforce $(\mathrm{Y})$ based on the processed output SPSS version 16.0, it can be seen in the Table Below. 
Table 1 Path coefficients of fighting spirit, confidence and motivation on students' readiness for work

\begin{tabular}{|c|c|c|c|c|}
\hline Variables & $\begin{array}{c}\text { Path } \\
\text { Coefficient }\end{array}$ & $\mathrm{t}$ & $\mathrm{F}$ & Sig \\
\hline $\begin{array}{l}\text { Power Struggle }\left(\mathrm{X}_{1}\right) \text { to } \\
\text { Readiness Entering the } \\
\text { World of Work }(\mathrm{Y})\end{array}$ & 0.357 & 4.916 & 102.030 & 0.000 \\
\hline $\begin{array}{l}\text { Attitude Confidence }\left(\mathrm{X}_{2}\right) \\
\text { on Readiness Entering the } \\
\text { World of Work }(\mathrm{Y})\end{array}$ & 0.127 & 2.577 & & 0.011 \\
\hline $\begin{array}{l}\text { Motivation }\left(\mathrm{X}_{3}\right) \text { on } \\
\text { Readiness Entering the } \\
\text { World of Work }(\mathrm{Y})\end{array}$ & 0.405 & 5.472 & & 0.000 \\
\hline
\end{tabular}

From the data processing of the above can be formulated and track structure variables influence the causes (exogenous) to the result variable (endogenous variable) in the following figure:

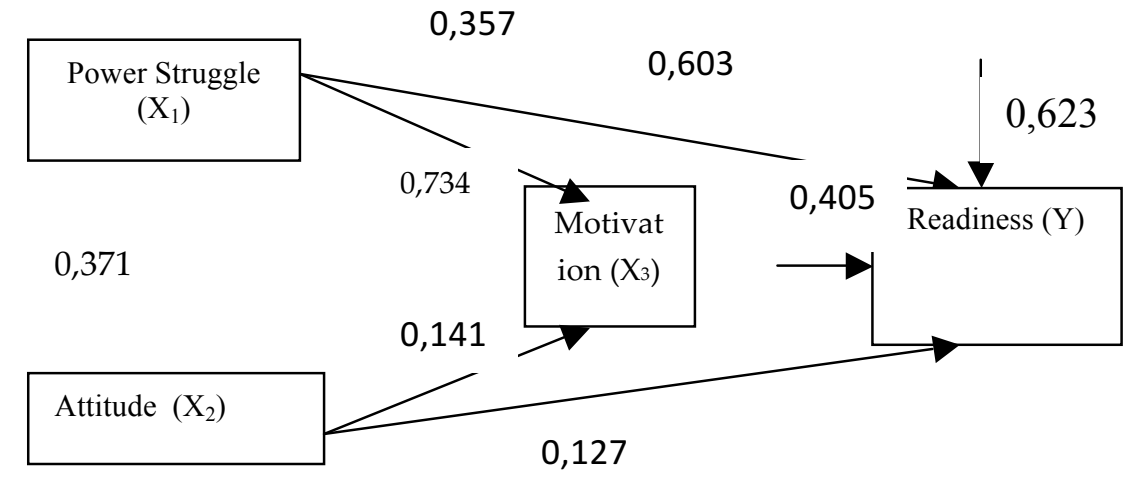

Figure 2 Structural Relationships $\mathrm{X}_{1}, \mathrm{X}_{2}$, and $\mathrm{X}_{3}$ on $\mathrm{Y}$

Table 1 shows $\mathrm{F}$ value of 102.030, this shows that the combination of fighting spirit, confidence and motivation is significantly influence the readiness for work. The detailed results of each path coefficient of fighting spirit, confidence and motivation, and work readiness are follows.

a. The effect of fighting spirit on readiness to enter the workforce.

$\mathrm{pX} \mathrm{X}_{1} \mathrm{Y}$ path coefficient $=0.357$, with significant thit $=49160.000>0.05$. it can be seen that the path coefficient willpower significant effect on the readiness to enter the workforce. Meaning increased score willpower can increase the score readiness to enter the workforce.

b. The influence of attitude on workforce readiness

$\mathrm{pX}_{2} \mathrm{Y}$ path coefficient $=0.127$, with significant thit $=2.577$ for $0.011>0.05$. it can be seen that the path coefficient confident attitude significantly influence the readiness to enter the workforce. Meaning increased score a confident attitude can improve the score readiness to enter the workforce.

c. The influence of motivation on workforce readiness to enter the workforce.

$\mathrm{pX} \mathrm{X}_{3} \mathrm{Y}$ path coefficient $=0405,5472$ with significant thit $=0.000>0.05$. it can be seen that the path coefficient motivation significantly influence the readiness to enter the workforce. Meaning increasing motivation score can improve the score readiness to enter the workforce.

\section{Conclusions}

The results of this research show that fighting spirit $\left(X_{1}\right)$, confidence $\left(X_{2}\right)$ and motivation $\left(X_{3}\right)$ as intervening variables significantly influence students' readiness to enter the workforce $(\mathrm{Y})$ directly or indirectly. 
Based on the results and conclusions of research discussion above it can be given advice to students should be able to strive forward in addressing the problem, which starts with a practice control their emotions when encountering a lot of work, when given the task by the teacher should be done with pleasure. Always think positive when you get a warning or advice from teachers that would grow impatient nature on students, and when getting a problem can be overcome calmly and wisely so as to increase job readiness on each student's self.

\section{References}

Bandura, A. (1994). Self-efficacy. In V. S. Ramachaudran (Ed.). Encyclopedia of human behavior (Vol. 4, pp. 71-81). New York: Academic Press. (Reprinted in H. Friedman Ed, Encyclopedia of mental health. San Diego: Academic Press, 1998).

Bandura, A. (1995). Exercise of personal and collective efficacy in changing societies. Bandura, A. (Ed.). SelfEfficacy in Changing Societies, Cambridge University Press, Cambridge, pp. 1-45.

Brady, Robert. (2010). Work Readiness Inventory (ISBN 978-1-59357-767-4). Published by JIST Works, an imprint of JIST Publishing.

Caballero, C., Walker, A., \& Fuller-Tyszkiewicz, M. (2011). The Work Readiness Scale (WRS): Developing a measure to assess work readiness in college graduates. Journal of Teaching and Learning for Graduate Employability, 43-54.

Chin, Chou Chih. (2002). The Effects of Self-Efficacy on Career Choices and Job Readiness among People with Intellectual Disability in Singapore, Goh Li Li, Li Jen-Yi (Nanyang Technological University)

Fitriyanto. (2006). Ketidakpastian Memasuki Dunia Kerja Karena Pendidikan. Jakarta: Rineka Cipta.

Ghozali, Imam. (2006). Aplikasi Analisis Multivariate Dengan Program SPSS. Semarang: BP.UNDIP.

Idris. (2015). Aplikasi Model Analisis Data Kuantitatif dengan Program SPSS. Universitas Negeri Padang. Irianto. 2004. Statistik Konsep Dasar dan Aplikasinya. Jakarta: Kencana.

Kanfer, R. (1990). Motivation theory and industrial and organizational psychology. in M. D. Dunnette and L. M. Hough (eds.). Handbook of Industrial and Organizational Psychology, Palo Alto, CA: Consulting Psychologists Press, 1, 75-170.

Lauster. 2012. Tes Kepribadian. Jakarta: PT Bumi Aksara.

Linette Anthony, (2005). Employability Skill Readiness among Business Students. Howard University.

Maurer, T. (2001). Career-relevant learning and development: Worker age, and beliefs about selfefficacy for development. Journal of Management, 27(2), 123-140.

Sugiyono. 2008. Statistika untuk Penelitian. Bandung: Alfabeta.

Sofyan. 2014. Teori Motivasi dan Penerapannya dalam Penelitian. Yogyakarta: UNY Press.

Tanius, Erni, \& Susah, Suhana bt. (2015). Employability Skill Readiness among Business Students. Universiti Selangor, Malaysia.

Uno \& Umar. 2009. Mengelola Kecerdasan Dalam Pembelajaran. Jakarta: Bumi Aksara.

Uno. 2011. Belajar dan Faktor yang Mempengaruhinya. Jakarta: Bumi Aksara.

Undang-Undang RI No. 20 Tahun 2003 tentang Sistem Pendidikan Nasional.

Vithessonthi, C., \& Schwaninger, M. (2008). Job motivation and self-confidence for learning and development as predictors of support for change. Journal of Organisational Transformation and Social Change, 5(2), 141-157. doi: 10.1386/jots.5.2.141/1 